\title{
Epidural and brain abscess following Pearl Spot fish bone injury
}

Figure $\quad$ CT/MRI composite
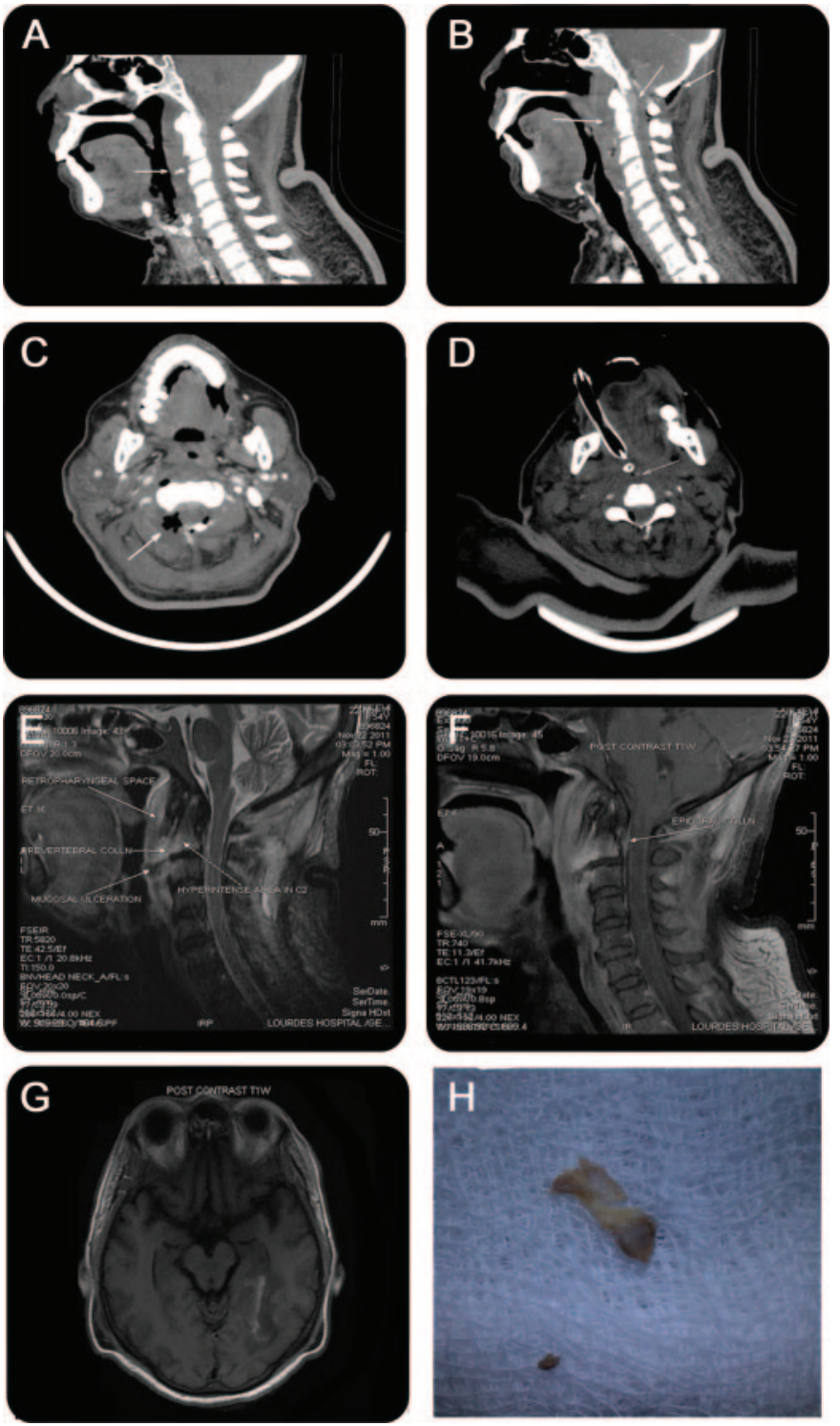

(A) Retropharyngeal radio-opaque foreign body. (B) Retropharyngeal space widening, cervical epidural collection, and posterior subcutaneous emphysema. (C) Axial CT image showing epidural and paravertebral emphysema. (D) Residual radioopaque foreign body in the retropharyngeal space after upper gastrointestinal endoscopic extraction. (E) Upper vertebral osteomyelitis and mucosal track. (F) Epidural abscess anterior to the cervical spinal cord. (G) Axial T1-weighted contrast image shows enhancing lesion in the left peritrigonal area. $(\mathrm{H})$ Two extracted pieces of Pearl Spot fish bone.

A 52-year-old woman developed headache, throat foreign body sensation, neck pain, and fever of 3 days duration 3 months after choking on a Pearl Spot fish bone (FB). CSF contained 2,200 cells, neutrophils (90\%) with normal sugar and protein. Brain MRI showed possible occipital cerebritis (figure). CT neck revealed a retropharyngeal foreign body, abscess and emphysema, and a pharyngeal fistula. Spine MRI dem- 
onstrated C2-3 osteomyelitis and epidural abscess (figure). The next day 2 pieces of FB were extracted from the upper esophagus. She died after 5 days. FB injury is common with unfilleted Pearl Spot fish consumption. Retropharyngeal abscesses can extend into the vertebrae resulting in osteomyelitis or cervical epidural abscesses. ${ }^{1,2}$

Boby Varkey Maramattom, MD, DM, Bright Thomas, DMRD, Dnbe, Kochi, Kerala, India

Author contributions: B.V. Maramattom primarily wrote and edited the manuscript. B. Thomas performed and interpreted the radiologic studies and edited the manuscript.

The authors report no disclosures relevant to the manuscript. Go to Neurology.org for full disclosures.

Correspondence \& reprint requests to Dr. Maramattom: bobvarkey@gmail.com

1. Frat JP, Godet C, Grollier G, Blanc JL, Robert R. Cervical spinal epidural abscess and meningitis due to Prevotella oris and Peptostreptococcus micros after retropharyngeal surgery. Intens Care Med 2004;30:1695.

2. Tsai YS, Lui CC. Retropharyngeal and epidural abscess from a swallowed fish bone. Am J Emerg Med 1997;15:381-382.

\section{NeuroImages Are Free at www.neurology.org!}

All Neurology ${ }^{\circledR}$ NeuroImages can now be freely accessed on the Neurology Web site. See them at www.neurology.org, where you can also sign up for journal email alerts and check out other online features, including the Resident \& Fellow section, Neurology: Clinical Practice, and the weekly Neurology Podcasts. 


\section{Neurology}

\section{Epidural and brain abscess following Pearl Spot fish bone injury \\ Boby Varkey Maramattom and Bright Thomas \\ Neurology 2012;79;484-485 \\ DOI 10.1212/WNL.0b013e3182617102}

\section{This information is current as of July 30, 2012}

\section{Updated Information \& Services}

\section{References}

Subspecialty Collections

Permissions \& Licensing

Reprints including high resolution figures, can be found at: http://n.neurology.org/content/79/5/484.full

This article cites 2 articles, 0 of which you can access for free at: http://n.neurology.org/content/79/5/484.full\#ref-list-1

This article, along with others on similar topics, appears in the following collection(s):

Spinal cord infection

http://n.neurology.org/cgi/collection/spinal_cord_infection

Information about reproducing this article in parts (figures,tables) or in its entirety can be found online at:

http://www.neurology.org/about/about_the_journal\#permissions

Information about ordering reprints can be found online: http://n.neurology.org/subscribers/advertise

Neurology ${ }^{\circledR}$ is the official journal of the American Academy of Neurology. Published continuously since 1951, it is now a weekly with 48 issues per year. Copyright Copyright (? 2012 by AAN Enterprises, Inc.. All rights reserved. Print ISSN: 0028-3878. Online ISSN: 1526-632X.

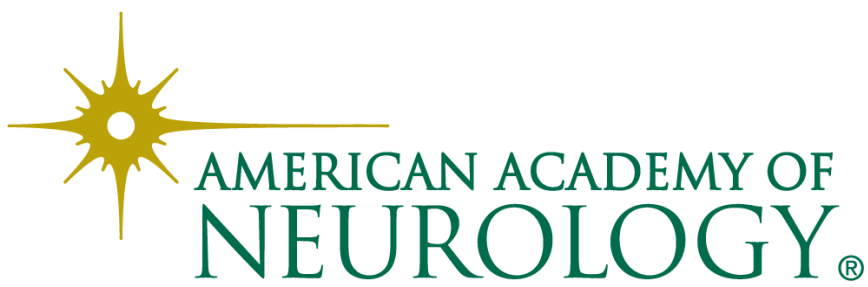

